\title{
“NARRATIVAS EM SITUAÇÃO DE PRISÃO”: OUTRAS HISTÓRIAS SOBRE JUVENTUDE, POLÍTICAS PÚBLICAS E CRIMINALIIDADE
}

\author{
"NARRATIVAS EN LA CÁRCEL": OTRAS HISTORIAS SOBRE \\ JUVENTUD, POLÍTICAS PÚBLICAS Y CRIMINALIDAD
}

\section{"NARRATIVES DEPRIVED OF LIBERTY": OTHER STORIES ABOUT YOUTH, PUBLIC POLICIES AND CRIMINALITY}

\author{
Vanessa Branco Cardoso ${ }^{1}$, Lutiane de Lara $^{2}$ e \\ Tiago Melgarejo do Amaral Giordani
}

${ }^{1}$ Universidade Federal do Rio Grande do Sul, Porto Alegre/RS, Brasil

${ }^{2}$ Centro Universitário Metodista, Porto Alegre/RS, Brasil

${ }^{3}$ Pontifícia Universidade Católica do Rio Grande do Sul, Porto Alegre/RS, Brasil.

\begin{abstract}
RESUMO: Neste trabalho, construímos um conto com jovens em situação de prisão na Cadeia Pública de Porto Alegre, onde buscamos trazer uma composição provisória sobre os cruzamentos das políticas públicas, da criminalidade e do neoliberalismo nas suas histórias de vida. Com estas narrativas, não buscamos destinos irreversíveis, nem respostas prontas, mas sim fragmentos, descontinuidades, a tecidura de um uso político da linguagem, a desterritorialização de significados preconcebidos das palavras. Assim, fazemos uso dos conceitos de narrativa de Walter Benjamin e de literatura menor de Gilles Deleuze e Félix Guattari.

PALAVRAS-CHAVE: Crime; Políticas públicas; Juventudes; Narrativas; Literatura menor.
\end{abstract}

RESUMEN: En este trabajo, construimos un cuento con jóvenes privados de libertad en la cárcel pública de Porto Alegre, donde buscamos traer una composición provisional sobre los cruces de las políticas públicas, de la criminalidad y del neoliberalismo en sus historias de vida. Con estas narrativas, no buscamos destinos irreversibles, ni respuestas listas, pero sí fragmentos, discontinuidades, la tejedura de un uso político del lenguaje, la desterritorialización de significados preconcebidos de las palabras. Así, hacemos uso de los conceptos de narrativa de Walter Benjamin y de literatura menor de Gilles Deleuze y Félix Guattari.

PALABRAS CLAVE: crimen; políticas públicas; jóvenes; narrativas; literatura menor.

ABSTRACT: In this article we built a short tale with young people deprived of liberty in the Porto Alegre Public Jail, where we sought to bring a provisory composition on the intersection of public policies, criminality and neoliberalism in their life histories. With these narratives, we do not seek irreversible destinations, nor rapid responses, but fragments, discontinuities, the fabric of a political use of language, the de-territorialization of the preconceived meanings of words. Thus, we make use of Walter Benjamin's narrative concepts as well as of the concept of minor literature by Gilles Deleuze and Félix Guattari.

KEYWORDS: Crime; Public policies; Youth; Narratives; Minor literature. 


\section{Introdução}

Compomos uma narrativa ficcional ${ }^{1}$ (Mota, 2011) sobre nossos encontros com jovens privados de liberdade em uma instituição prisional do Estado do Rio Grande do Sul. A Superintendência de Serviços Penitenciários aponta que $60 \%$ da população carcerária possui entre 18 e 29 anos (SUSEPE, 2017). Essa faixa etária é o público-alvo de intervenção e escuta qualificada do projeto "Observatório de Juventudes em Situação de Prisão”. Através da realização de entrevistas individuais e grupos focais, produzem-se dados quantitativos e qualitativos sobre a composição de uma trajetória de vida desses jovens, buscando histórias sobre educação, trabalho, família, saúde e acesso à justiça políticas públicas que são eixos temáticos da pesquisa.

Partindo dos pressupostos da pesquisa, entendemos que os caminhos que as pessoas em situação de prisão percorrem pelas políticas públicas sofrem um apagamento intencional, buscando-se reduzir suas vidas aos boletins de ocorrência, ou seja, à prática da criminalidade (Rauter, 2007). Isso impacta na garantia de direitos dessas populações, alijando esses sujeitos do seu protagonismo, fabricando-se existências ideais e forjando uma falsa igualdade entre as pessoas e criando a ilusão que todos têm possibilidades idênticas de gozar de seus direitos (Guareschi, Lara, \& Adegas, 2010).

De acordo com Foucault (2016), sobre estas populações escreve-se uma biografia criminal. Faz-se uma previsão de seus atos através do aparato técnico-judiciário-científico do Estado que autoriza práticas de vigilância e repressão aos desviantes. A virtualidade dos seus comportamentos passa a ser alvo de controle. Nessa perspectiva, não há saída para a delinquência ${ }^{2}$, uma vez que ela é normalizada e capturada. Porém, no encontro com os jovens em situações de prisão, percebemos que há cruzamentos da criminalidade e das políticas públicas, caminhos que constantemente se (re)traçaram, sempre em movimento, ora sendo capturados pelos jogos de poder, ora resistindo. Tomamos por resistência as possibilidades de afirmação de vida, a (re)invenção de si, a abertura de novas brechas em que não se havia pensado antes (Deleuze, 1988). No caso dos participantes da pesquisa, a própria criminalidade pode ser vista como um modo de deixar de ser passivo frente às demandas do mercado de consumo, mas também, o próprio crime pode ser absorvido pelo sistema e a resistência inicial acaba sendo capturada.

Em Deleuze e Guattari (2015), a literatura pode ser um meio de resistir, levando o autor aos seus próprios pontos de subdesenvolvimento. Pensando nisso, resolvemos apresentar as narrativas dos jovens privados de liberdade através da produção literária. Inspiradas em Giordani $(2016)^{3}$, tomamos a ficção como instrumento neste trabalho, criando um conto - uma pequena narrativa sobre temas da vida cotidiana - a partir do ponto de vista de uma narradora: A Política - uma composição provisória, resultado de engendramentos macropolíticos e ações micropolíticas (Bernardes, 2012) que promovem modos de viver em uma complexa trama que articula políticas sobre a vida e políticas da vida. Assim, ao narrar a vida do protagonista, ela também se constitui, se coloca em questão, narra sua própria história (Benjamin, 1987). Já o protagonista, que encarna os relatos dos jovens em situação de prisão, chama-se apenas $\mathrm{Corpo}^{4}$. O que para nós é proposital, uma vez que é nele que se inscrevem os acontecimentos ${ }^{5}$ (Foucault, 2017) e onde as instituições deixam as suas $\operatorname{marcas}^{6}$ (Goffman, 1961). 
Nesta narrativa não pretendemos criar representações das pessoas que nos confiaram suas histórias, nem extrair suas essências. E sim, ao contrário, desmontá-las, falar de fragmentos, de agenciamentos possíveis. Nosso objetivo é de aproximarmo-nos do conceito de Literatura Menor (Deleuze \& Guattari, 2015), desterritorializando a língua, fazendo usos menores das palavras, promovendo agenciamentos coletivos de enunciação. A partir disso, pretendemos nos opor às grandes produções, valorizando o que há de mais singular e provisório nas histórias de vida. Assim, não se narra um estereótipo, mas sim possibilidades de enunciação de um coletivo. Não falaremos de destinos irreversíveis, não há versão final dos acontecimentos, não há diagnóstico, e nem veredicto. Esta é uma mistura não-homogênea de pessoas que compartilham uma experiência, criam uma linguagem, formatam seus corpos, encontram uma forma de (sobre)viver às condições subumanas de estar privado de liberdade.

Este conto só é possível neste instante. Nasce descompromissado da produção de dados formais, em uma tentativa de dar vazão a essas histórias para dentro do espaço acadêmico. Perseguimos o intermezzo, costurando os saberes acadêmicos com os saberes da experiência (Giordani, 2016). Acolhemos histórias, experiências, impressões, ficções, produções artísticas, o dito e o não-dito no encontro com os jovens em situação de prisão na Cadeia Pública de Porto Alegre. Também se fazem presentes nossas próprias experiências: textos acadêmicos, literários, músicas, documentários, filmes, diário de campo, obras de arte, poesias, vida cotidiana e até os noticiários policiais. Tudo isso está mais ou menos diluído neste trabalho, de acordo com o espaço limitado que temos para fazê-lo neste momento.

Queremos apontar algumas direções, fazer algumas indicações ao leitor para experimentar esta narrativa cheia de buracos, brechas, aberturas. A fragmentação e a falta de respostas são intencionais no texto, pois esta permeabilidade traduz nossos encontros com os jovens privados de liberdade. O texto é composto de (a) introdução; (b) um conto político; (c) fragmento de diário do corpo e (d) diário da política. Na sequência, apresentamos o conto no qual nos utilizamos imensamente das notas de rodapé, não apenas como notas explicativas, mas também como meio de trazer referências acadêmicas, literárias e artísticas que nos inspiraram a escrita, que se fizéssemos de acordo com as regras, interromperiam o fluxo da narrativa. Por esse motivo, tomamos a liberdade de cometer essa pequena transgressão. Logo após o término do conto, há uma abertura de passagem para a fala do Corpo, onde a sua linguagem ganha espaço no texto, e vemos um ensaio do processo de narrar a si mesmo. Depois é a vez do post-scriptum da Política, em forma de diário, que tem o objetivo de trazer uma discussão teórica mais aprofundada, mas que não deixa de lado a experiência. Essa é a ordem que pensamos para te apresentar. Porém, a descontinuidade neste trabalho é intencional. A nossa indicação é a mesma que Giordani (2016) fez na sua tese-romance: faça seu próprio percurso pelo texto. Se você quiser começar por qualquer parte não terá prejuízo no entendimento. Abra seu próprio caminho, pois deixamos apenas pistas para a sua leitura, mas esperamos que faça a partir de suas próprias referências. 


\section{Um conto político}

O corpo de quem falo aqui ainda não está em situação de prisão, mas é como se nascesse para ir para o Sistema Prisional. Sua cor, sua localização geográfica, sua posição no mercado de consumo me faz lembrar um rap dos Racionais MC's na década de 90: "minha vida não tem tanto valor, quanto seu celular, seu computador". O Corpo $\mathrm{mau}^{7} / \mathrm{mal}$ nasceu e já sente a dor de precisar algo que não tem, que não pode acessar, que ele nem sabe o que é. Ele não sabe, mas sente desesperadamente. Eu também conheci sua mãe. Ela foi usuária de drogas durante a gestação e recebeu cuidados em um centro especializado de saúde, onde muitos corpos em situação de rua, como ela, eram atendidos. Foi assim que nos encontramos pela primeira vez: o Corpo e eu. Ele ainda no ventre da mãe, as células a todo vapor crescendo, se especializando, formando as "peças" do seu corpo-máquina. Eu achava tudo aquilo lindo, pois havia várias possibilidades em uma só existência. Tudo se montando e desmontando conforme o corpo crescia dentro daquela máquina-mãe de fazer vidas. Porém, para alguns a Mãe do Corpo era uma fábrica de reprodução de mazelas sociais, e aquele pequeno ser já era apontado como "futuro marginal" ou pior ainda, "um sem futuro". Já havia discursos e determinações sobre vida dele. Muitos tinham convicção de que ele não tinha condições de ser um cidadão, devido às circunstâncias em que se daria seu nascimento. O Corpo estava à deriva. E nem tinha nascido.

Me desculpe! Que falta de educação a minha! Não me apresentei... Prazer, sou a Política. Deves me conhecer pela minha atuação como política pública. Espero que não me conheças apenas como política partidária, pois não é disso que falaremos aqui. Apesar de falar como uma única voz aqui, sou múltipla. Atuo em diversas frentes: família, educação, trabalho, assistência social, saúde, habitação, previdência social, justiça, entre tantos outros. Sou resultado de jogos de poder que negociam constantemente com a operacionalização dos direitos das pessoas, presente nas ações macropolíticas e cotidianas do cenário público. Vivo em meio a uma queda de braço do combate à desigualdade e controle das populações ${ }^{8}$. E essas são as duas faces de um mesmo acontecimento que fazem parte da minha composição ${ }^{9}$.

Sou composta por experiências massificadas sobre as vidas dos sujeitos, sou feita de intervenções pensadas em existências ideais. Estou presente nas instituições, onde conheço e produzo dados sobre aqueles que passam por mim. Mas também sou acesso a direitos fundamentais das pessoas. Infelizmente, quanto mais desiguais as populações, mais assimétricas são suas condições de acesso. Muitas vezes, sou vista como um favor e não como um direito. Entretanto, não te esqueças: se em alguns pontos da trajetória me encontras engessada, em outros pontos me encontrarás fluida. Cada encontro entre nós será único. Eu não serei mais a mesma, nem você. Enfim, já falei demais de mim. Acredito que a história que mais importa ainda está por vir, e ela está se compondo junto com a história do Corpo.

O que eu dizia sobre o Corpo é que me dói ver algo tão pequeno ser objeto de uma amarração onde as diferentes possibilidades de vida são reduzidas, apertadas até o limite. Apontam-se falhas como resultado de um processo individual e não como uma falta de suporte para determinadas existências que são direcionadas ao encarceramento e extermínio por não se encaixarem no projeto neoliberal. Contudo, o Corpo não se renderia tão fácil. Ele tinha muita vontade de viver, brigava pela vida e não se deixaria exterminar tão fácil. Mesmo nascendo em meio a uma série de expectativas sobre sua morte, mesmo que muitos achassem que já "sabiam o que ele iria virar", ele não desistiria sem lutar. 
Vejo que virtualmente tudo estava programado para a curta trajetória da alma e do corpo do Corpo na Terra. Mas por uma série de fatores que escapam a quem deseja controlar o destino, a Mãe do Corpo teimava em não lhe dar ouvidos. Ela queria gerar aquela vida. Estava disposta a tornar a existência do filho menos doida que a dela.

O Corpo nasceu e ela deixou um bilhete com um número de telefone de uma pessoa que sabia que não iria falhar na missão de fazer aquele corpo viver. O Pai do Corpo foi localizado e respondeu com brevidade ao chamado. Ele já era pai solteiro de uma menina e um menino, quando namorou com a Mãe do Corpo. Sem anunciar sua gravidez, ela desapareceu. E agora havia lhe deixado essa responsabilidade. Ele nem sabia da sua gravidez quando ela desapareceu. Portanto, ficou surpreso. Estava feliz e preocupado, pois sua vida não era fácil, mas não hesitou em prometer que faria o melhor que pudesse pelos seus filhos. $\mathrm{O}$ Pai trabalhava muito. Havia construído com muito suor e um pouco de malandragem uma pequena oficina mecânica no pátio de sua casa. Com o dinheiro que ganhava ali sustentava a família. Moravam em uma pequena casa, sem luxo, em uma encosta de morro, mas era o suficiente para sua família. O Corpo crescia e perguntava: “onde está a minha mãe?” E o pai respondia: "Eu sou teu pai. Isto basta”. Ele não sabia como lidar com a situação, mas cuidou muito bem do Corpo. Não deixou lhe faltar "afecto" ${ }^{10}$ e supriu ("suprimiu") suas necessidades.

Quando o filho completou idade em que obrigatoriamente deveria começar a frequentar a escola, o Pai fez sua matrícula em uma instituição próxima de casa. No primeiro dia de aula, o Corpo chegou lá e viu uma de minhas várias facetas ${ }^{11}$ : a promessa de um lugar que lhe abriria um novo mundo de descobertas e aprendizagem. E assim se fez - viu a imagem do descaso e precarização: turmas lotadas, professores no limite do estresse, salas de aula mal equipadas e não preparadas para promover a equidade. Em nenhum momento eu disse que o aprendizado seria algo fácil. Apesar dele ainda não entender toda essa complexidade, viu que havia algo "errado"(!!??), teve medo e gritou: "Eu quero voltar pra casa! Quero brincar na rua! Não quero ficar aqui”. Entretanto, não tinha saída. Foi assim que o Corpo conheceu as grades. Ao se deparar com elas, percebeu que estava preso e que nada era natural naquele lugar. Pensou que as grades que iam do chão ao teto para impedir a fuga das crianças já que lhes impunham que ficassem muitas horas sentadas e que não se mexessem muito. Soube que só sairia dali quando lhe permitissem. Sentiu-se sufocar.

O Corpo já conhecia regras e limites dentro da sua família, o Pai ensinou-lhe a cuidar de si e dos outros, mas não havia uma relação de vigilância constante. Por isso, espantou-se com a rigidez da rotina da escola. O Corpo sentiu-se paranoico e violentado. Reclamou com seu pai, ao chegar em casa, disse que não queria voltar para aquele lugar. Seu pai explicavalhe que a escola era um mal necessário ${ }^{12}$ para que ele "fosse alguém na vida" e "tivesse um futuro". E eu ficava admirando a fé das pessoas simples na Educação, acreditando que ela pode mudar a vida de seus filhos. Talvez pensassem que eles poderiam se inserir em um outro lugar nas relações de poder. Mal sabem eles que a própria instituição se tornou um lugar privilegiado de produção de informações sobre populações periféricas, especialmente no que diz respeito à construção sobre seus antecedentes criminais ${ }^{13}$. Da conversa com seu pai, o Corpo extraiu que ele queria "ter um futuro". Ele sempre quis, mesmo quando disseram no útero da Mãe que ele não sobreviveria. Com o tempo, foi se resignando à Escola, acatou suas regras e fez o possível para passar por ela, sem que ela o amarrasse. Mas é possível sair da Escola ${ }^{14}$ sem ser amarrado? 
O Corpo foi crescendo e secretamente (nos coletivos que transversalizam nossa experiência de viver) encontrando meios para continuar resistindo. Um dos meios que encontrou para levar adiante essa resistência foi a arte. Não a arte dos museus ou a arte clássica, mas sim com uma forma marginal de arte: o hip hop ${ }^{15}$. O Corpo achava a maioria das tarefas escolares uma atividade chata e sem sentido, já que a escola priorizava versos escritos por pessoas que já estavam mortas ou então que ele não entendia a maioria das palavras. Ficou encantado quando a Professora lhe falou a respeito do hip hop, um velho conhecido seu, como uma expressão artística. Ela o incentivou a pesquisar imagens, textos, músicas, poesias onde ele pudesse reconhecer suas referências culturais. Um campo de imanência se compôs através deste dispositivo e novas possibilidades se fizeram presentes. Ele passou a perceber que a história da sua gente era desvalorizada frente às grandes produções que retratavam um povo homogêneo e idealizado, o que nem de perto representava sua trajetória. A forma como as palavras eram empregadas, diversa daquela que era aprendida na escola, levou-o a compreender a importância da criação de dialetos, de expressões próprias que havia nas músicas que ele admirava. Percebeu que havia um sentido político nelas, que ligava pessoas que passam por uma mesma experiência ${ }^{16}$.

Esses acontecimentos provocaram no Corpo a vontade de escrever histórias. Na sua composição, ele não se importava com a gramática e a ortografia normativa, mas sim com os afectos ${ }^{17}$ que o moviam, com os fluxos que o transversalizavam. Suas palavras tinham o "peso" da responsabilidade de falar de uma experiência compartilhada das pessoas que eram próximas a ele, da sua origem, tão violentamente apagada dos livros didáticos. Passou a se sentir menos sozinho. Passou a nomear seus sentimentos e perceber que essa sensação era algo que vinha antes dele. Era algo que seu Pai já sentia, e antes dele seu Avô. Eu, que caminho por estas fronteiras, preciso teorizar, mas o Corpo não, tinha um saber empírico que apenas os "maloqueiros" têm ${ }^{18}$ e que agora tinha palavra.

Ele passou a pensar que a música também une os corpos. Aproximou-se de outros sujeitos e compartilhou o que sentia ao ouvir o hip hop. Mesmo que silenciosamente, todos sentiam-se ligados. Na saída da escola, no seu tempo livre, na rua eles se reuniam para ouvir música. Eram um só ouvido aprendendo as letras, uma só boca cantando-as. Com o tempo, o grupo de amigos foi aumentando e pessoas diferentes foram se aproximando com novos sons e novos objetivos foram surgindo. Aos poucos o funk foi sendo introduzido na lista de músicas. O Corpo resistiu, pois apesar da batida dançante, o conteúdo das letras era menos social e mais erótico. Não que isso não fosse uma demanda sua também, mas ele queria preservar este espaço de reflexão com os amigos. Porém, a introdução do novo ritmo atraiu cada vez mais novas pessoas para a roda de amigos, especialmente as meninas que se aproximavam para dançar. O funk acabou ganhando espaço na sua convivência e rap acabou ficando cada vez mais restrito à apreciação solitária.

A mudança na estética e na sonoridade aproximou a Menina. A atração do Corpo por ela foi instantânea: simpática, bonita, com um corpo escultural e dançava feito bailarina. Ela andava sempre muito bem arrumada, com roupas de marca que marcavam os contornos de seu corpo feito de formas perfeitas e cabelos super bem cuidados. O Corpo, de corpo "franzino", sentiu-se diminuído, e pensou que a Menina nem sabia da sua existência. Ele era apenas um corpo qualquer, sem roupas legais, sem celular, sem nada. Ele só tinha o seu próprio corpo coberto com roupas surradas. Sentiu-se mal por isso. Dentro dele, conviviam a vontade de ter objetos que falassem por ele e o pensamento da relação perversa que o consumo tem com os corpos da periferia, que havia aprendido com o rap. Até o momento, 
ele estava disposto a "ser alguém" e não apenas a ter algo. Não queria que as coisas falassem por ele. Entretanto, há bastante tempo ele havia percebido que o dinheiro possibilita acesso àqueles que foram discriminados a vida inteira. E o Corpo sentia-se excluído e ridicularizado. Ele passou a entender, pois muitos ao seu redor admiravam o estilo "vida loka ${ }^{19 ”}$. Alcançar seus objetivos por meios ilegais parece ser o único caminho para muitos saírem da invisibilidade. O Corpo via cada vez menos saídas do sonho neoliberal.

Esse problema passou a ocupar muito tempo na sua mente. Pensava em várias estratégias para conseguir se apresentar melhor na frente da Menina e dos amigos. Uma delas era trabalhar na oficina do pai para ganhar algum dinheiro. Contudo, não achava certo cobrar do pai pelo seu serviço, pois sabia que o pai nunca havia lhe cobrado por nada. Não achava justo. Onde então ele poderia conseguir dinheiro? Onde ele poderia trabalhar? Um amigo lhe convidou para ir para uma seleção de emprego em uma rede de supermercado que empregava menores de idade como aprendizes. Ele tentou preencher a ficha com uma série de informações que ele não tinha, e que nem sabia que precisava. Preocupado em entregar incompleto, solicitou a ajuda da recepcionista. A mulher o olhou com desdém, fixando o olhar em seus tênis velhos, e arrancou-lhe a prancheta da mão, mandando-o embora. Ele nem foi entrevistado. Não entendeu por quê. Fez muitas outras tentativas, frequentou cursos e palestras, via outros jovens sendo selecionados para começar suas atividades nas empresas, mas ele não. Ouviu que ele não era adequado aos perfis que as empresas procuravam. Ele desconfiava que a cor de sua pele era a responsável pela rejeição. Sentia-se cada vez mais frustrado. Ficou com muita raiva quando apesar de seus esforços não teve uma oportunidade. Mesmo assim continuava resistindo aos convites de seus amigos para cometer crimes: "Cara, nóis faz uma mão ${ }^{20}$ rapidinho ali”. E quando olhava para esses amigos, que andavam sempre com roupas novas e ficavam com todas as garotas, pensava nos riscos que eles corriam. Não queria isso para seu pai, sua família e nem para si. Entretanto, contra sua vontade, essa vida parecia cada vez mais atraente.

Ele tinha um Amigo mais próximo a quem recorria quando precisava "esfriar a cabeça”. O Amigo trabalhava como empacotador de um supermercado para encobrir as suas correrias ${ }^{21}$ de sua mãe, tendo uma procedência para o dinheiro com que aparecia em casa. Contudo, o Corpo sabia que ele era integrante da facção criminosa que comanda o tráfico na região. Eles tinham uma boa relação desde a infância e podiam contar um com o outro, ajudando-se mutuamente nas horas mais difíceis. O Amigo nunca teve pai, e o Corpo não conheceu sua mãe, isso os uniu de certa forma. Eles trocavam muitas experiências sobre suas faltas e se tratavam como irmãos. O Amigo considerava o Gerente ${ }^{22}$ da "boca" como alguém, uma figura paterna, que lhe dava roupas, dinheiro e conselhos sobre como chegar nas meninas. O Corpo tentou inúmeras vezes dissuadi-lo desse modo de vida, dizendo que ele faria parte dos dados que só aumentam em relação à criminalização e extermínio da juventude negra, pobre e periférica ${ }^{23}$. Ouviam músicas juntos e refletiam sobre isso. O Amigo lhe explicava que a revolta e a raiva o levaram para o crime, pois a criminalidade tinha a porta sempre aberta e recebia a todos, enquanto a do trabalho era difícil e humilhante, como o Corpo mesmo pôde sentir na pele.

Certo dia, os dois estavam na esquina conversando, quando a Menina se aproximou e perguntou se eles iriam ao baile funk daquela noite. O Corpo queria muito ir, mas não tinha dinheiro ou roupas que considerasse adequadas. Não se sentia à altura daquela garota. O Amigo tomou a iniciativa e disse: "Nós vamos, sim. Eu e meu brother aqui". A Menina sorriu e seguiu seu caminho. O Amigo empolgou-se e convenceu o Corpo que essa era a 
sua chance de conquistá-la. Disse que emprestaria suas roupas e acessórios para montar um visual impressionante. Levou o Corpo até sua casa e o fez vestir-se. Quando se olhou no espelho, se sentiu confiante. Com o incentivo do Amigo, ensaiava como chegar na Menina. Ele sorria.

Foi então que alguém bateu à porta. O Gerente chegou na casa à procura do Amigo e vendo o Corpo o elogiou. Corpo agradeceu e já ia se retirando, mas foi educadamente convencido a ficar. O Gerente fez uma proposta para o Amigo, e disse que se o Corpo quisesse também poderia participar. Era "jogo rápido” e ganhariam muito dinheiro para gastar no baile. "A segunda grande chance do dia", disse o Amigo. O Corpo ficou muito confuso, não sabia o que responder e nem como agir. Sabia que não se dizia não de cara para uma pessoa dessas. E mais do que isso: não sabia se queria ou não participar do esquema. Desejava muito aquele dinheiro e o que ele podia lhe proporcionar. Estava cansado de tanto resistir. Seu desejo foi tão intenso que embaralhou até os meus sentidos e eu pouco consegui ver o que aconteceu a seguir. Tudo virou limbo para mim. Não pude alcançá-lo. Eu não sei se ele aceitou a proposta ou não. Não sei se ele chegou a ir ao baile. Eu não sei de nada. Mas isso não importa, já que eu não sou juiz.

Quando eu encontrei o Corpo novamente, ele estava espancado, torturado, apenas tentando sobreviver em uma cela fria. Algemado, sem roupas, sem comer há dois dias. Ele estava com mais 20 pessoas em poucos metros quadrados. Ele não conhecia ninguém. Quando abriu os olhos, a luz lhe feriu. Uma voz perguntou: "Quem tu é? Onde tu mora? Fecha ${ }^{24}$ com quem?”. A voz parecia vir de longe, mas vinha de um rapaz que estava de pé na sua frente. Ele não conseguiu responder, a voz não saía. O rapaz ficou irritado e insistiu. O Corpo com esforço disse seu nome e onde morava. Logo, o rapaz identificou que o Corpo residia na área da mesma facção a que ele pertencia e, portanto, não era um inimigo. Se fosse, estaria pronto para matá-lo. Deixou-o em paz. O Corpo estava com muito medo, mas não podia deixar que os outros percebessem. Ele estava em frangalhos, porém sabia que se chorasse seria interpretado como fraco pelos demais. Não conseguia suportar a visão daquelas grades, elas o apertavam, o comprimiam, o diminuíam. Reduziam sua capacidade de falar. Então resolveu ficar quieto. Aos poucos, foi interpretando o ambiente e vendo que não eram apenas as grades que o prendiam. Havia a polícia, as organizações criminosas, seus companheiros de cela, a vigilância constante de todos os lados. Era preciso aprender a se comunicar. Era preciso se adaptar para sobreviver. E mais do que isso era preciso aprender a mapear as pessoas: ler o que elas queriam dele. Ele não tinha amigos dentro da prisão, tinha apenas parceiros, pessoas a quem precisava se associar para continuar vivo. Se confortava pensando que aquele era um lugar de passagem, e com sorte, rápida.

A visita dos familiares, apesar de causar dor, era muito importante. E vital. Já nos primeiros dias ele pôde perceber isso quando ficou gravemente doente em função da falta de higiene da casa prisional. Foi vitimado pela "zica da cadeia”, desordem orgânica resultante da dificuldade do corpo humano em se adaptar às condições de extrema insalubridade do ambiente carcerário. Seus companheiros de galeria tiveram que interceder junto à Brigada Militar para que ele conseguisse atendimento na Unidade Básica de Saúde Prisional e pudesse ter sua saúde recuperada. A partir disso, o Corpo viu o quanto era fundamental a "sacola" que o Pai trazia todas as semanas, onde vinha não apenas comida, mas também itens de higiene e limpeza, medicamentos, roupas de cama e outros itens necessários à sua sobrevivência. 
$\mathrm{Eu}$, vendo tudo isso, refletia na trajetória que o Corpo havia traçado até aqui. Estar privado de liberdade fez com que ele pensasse que todas as outras possibilidades de existência haviam se apagado. O Corpo foi empurrado para uma identidade fixa de "bandido". As pessoas que estavam privadas de liberdade como ele adotavam o ser "bandido" com orgulho, como se ao assumir esse estigma criassem uma maneira de lidar com as condições desumanas a que estavam submetidas. Fechavam-se procurando proteção. Procuravam esquecer-se que eram filhos, irmãos, homens, meninos. Eram muitas coisas e não podiam se definir por estar em situação de prisão.

O Corpo se sentiu capturado por essas forças também. Viu-se tão desesperado que criar um território identitário foi um modo de lidar com a situação de estar encarcerado. Mas como eu já contei para vocês, o Corpo sempre foi teimoso e insistia em secretamente agenciar novas experiências. Portanto, apesar de parecer que ele só desejava sobreviver na prisão, ele estava criando espaços dentro dele para guardar o Corpo-menino, repleto de arte, cheio de hip hop. Meio dentro, meio fora, estava viva a vontade que mais o animava, que não o abandonava mesmo nos momentos de maior escuridão: a enorme vontade de viver. Como eu sei disso? Encontrei escondida em seus pertences uma folha de papel rasgada, rasurada, dobrada e nela algumas palavras. Um fragmento. Uma inquietação. Um passeio por alguns momentos de vida. Uma história sendo construída sobre si mesmo, com suas palavras, a seu modo.

\section{Um fragmento de diário do Corpo}

Eu sinto muita saudade do meu pai, dos meus irmãos, dos meus amigos, de poder caminhar pela rua e ir até um mercadinho pra comprar um refrigerante, de dormir na minha cama limpa e confortável, de respirar ar puro, de andar de carro, de ônibus, de correr. Mas eu caí aqui e fico pensando, será que era pra eu passar por isso mesmo? Meu pai queria que eu ficasse na escola. Mal sabia ele que é lá, muitas vezes, que tu conhece os indivíduo do tráfico. E pode começar o envolvimento. Eu ficava sereno na minha, ouvindo meu som. Via muito moleque se dando bem no crime enquanto eu ficava pra trás. O meu melhor amigo era da pá virada desde piá, ele cresceu no meio da função ${ }^{25}$. Ele não ia muito à escola, a gente se via mais na rua mesmo. Ele me fazia vários convites. Eu resistia. Mas vou te contar: desde os 14 ou 15 anos o cara tá perdido: é crime, festa e mulher, o tempo todo na tua volta. Pra mim, as mina foram a pior parte: se elas me pediam pra matar aula, eu ia. Vi amigos que começaram a usar drogas, só pra fumar um baseadinho com elas. Se elas querem ir pra festa, a gente vai fazer o que for pra ir com elas. E ninguém quer sair sem dinheiro. Na real, não tô dizendo a culpa é das mina, não é a guria que influencia o cara... é a vontade que a gente tem de pagar de grandão. E infelizmente, se tu tem dinheiro, as minas vem ao natural. Elas também gostam de dinheiro que nem todo mundo, né? Cada um arruma um jeito de se destacar. Mas eu não tô procurando culpado de eu estar aqui não. Apesar de muita gente querer me culpar e me trancar aqui. Eu não acho nem as minas, nem a escola, nem a família são culpadas... pra mim é o vício no dinheiro! Sei lá, tem muita coisa em jogo. Eu preciso é focar em sobreviver a isso aqui. E eu estou vivo, irmão! ${ }^{26}$ 


\section{Pós-escritos (diários)}

\section{6 de maio de 2017}

Hoje comecei a escrever a história do Corpo e me vi pensando a respeito de um autor que eu gosto muito: Franz Kafka. Ele escrevia cartas, romances e diários. Inspirei-me nele para fazer meu próprio diário. Comecei escrevendo sobre como me intriga a situação atual do sistema prisional, como ela se tornou possível e como o Corpo acabou indo parar lá.

Parto do ponto de vista que foram criados discursos para sustentar que determinadas populações sejam clientela principal do sistema carcerário. Nesse ponto, me deparo com as ideias de Foucault (2005) sobre o nascimento das ciências humanas no século XIX e com elas o aperfeiçoamento dos mecanismos punitivos. A prisão recebeu "um exército inteiro de técnicos [que] veio substituir o carrasco" (Foucault, 2017, p. 20). Houve a transformação do papel do juiz e do julgamento, não ficando resumidos à sentença, mas sim a uma série de instâncias anexas - guardas, educadores, médicos, psiquiatras, psicólogos, entre outros. Esse foi o surgimento de todo um complexo científico-judiciário que passou a amparar a justiça no seu poder de punir.

Passou-se a investir na construção de uma biografia do delinquente, onde se buscou amarrar vida pregressa e infração, ligando-as de maneira artificial, de forma que criminoso e crime não possam um existir sem o outro. As notícias policiais acabam tendo um papel fundamental na construção da desumanização do delinquente, criando e fortalecendo uma polarização entre "criminosos" e os "cidadãos de bem". Passa-se a autorizar todo o tipo de práticas de vigilância, punição e até extermínio para garantir a segurança do restante da população (Bauman, 1998; Coimbra, 2006; Foucault, 2017).

Para estes sujeitos, constrói-se uma identidade criminosa - que virtualmente já vinha sendo montada desde seu nascimento -, realiza-se um levantamento sobre a sua periculosidade. Retomo a recordação do início deste diário: Kafka, mais especificamente a obra O Processo. Deleuze e Guattari (2015) afirmam que Kafka estava preocupado em desmontar toda ideia de culpa através da experimentação do personagem pelos caminhos tortuosos da justiça. Os autores chegam a afirmar que ser inocente era a pior das hipóteses, pois passar por toda a angústia que prevê um processo não valeria a pena se não se fosse culpado. Nessa história, no processo de K., o protagonista, não importam as provas, mas sim saber como acessar as salas contíguas, os corredores, os bastidores dos julgamentos e encontrar uma saída. O que importa são os cochichos, as conversas informais e os barulhos atrás da porta (Deleuze \& Guattari, 2015). Compondo com essa visão, Foucault (2017) diz que não são os juízes que prendem os acusados, mas sim os técnicos "anexados" ao processo penal, aqueles que para Kafka estão na sala ao lado.

Encerro por hoje pensando junto com estes autores: a justiça produz determinadas existências como delinquentes e dificulta que eles possam sair deste emaranhado judicial, feito para mantê-los dentro. Contudo, não podemos pensar que estes corpos são passivos frente aos acasos. Eles resistem, traçam novos mapas de intensidades, formam-se e deformam-se de diferentes maneiras, conforme diferentes agenciamentos, construindose pedaço a pedaço, não se deixando reduzir uns aos outros. A própria justiça é desejo movente (Deleuze \& Guattari, 2015), pois não julga da mesma maneira os iguais, 
mas sim conforme seus próprios funcionamentos. Dessa maneira, encontram-se brechas. Enfim, vou largar a caneta por ora e pensar como isso interfere na minha própria atuação e como ora sou atravessada pelo neoliberalismo, ora encontro resistência "atrás da porta" como fazia K.

\section{1 de junho de 2017}

Hoje eu contei mais um pouco da história do Corpo. Comecei a pensar na narrativa dele como uma forma de denunciar o apagamento intencional que as histórias que corpos como ele vêm sofrendo ao longo do tempo. Eles não têm direito às suas versões nos grandes meios de comunicação, que acabam por pintá-los como pessoas irrecuperáveis, perversas e extremamente perigosas. E não como um produto do modo de vida da própria contemporaneidade.

Pensei nisso, visitando uma das obras de Bauman (1998). Eu me vi de boca aberta pensando: a própria racionalidade neoliberal produz os "jogadores inaptos" como produto esperado e desejável. Eu falava em voz alta como se dessa forma eu também pudesse me compor de uma maneira diferente a partir desse saber. Me questionava: o sistema que muitos defendem como um meio de alcançar a igualdade produz também os "perdedores"? Sim, ele produz e faz disso uma estratégia para que os demais continuem seguindo em frente, custe o que custar, para que eles não se transformem nos últimos da fila. Escondem-se atrás da falácia da meritocracia, ignorando que os "fracassados" não tiveram nem as condições básicas para competir entre os "jogadores", mas que, mesmo assim, são constantemente bombardeados pelos ideais do consumo.

Nos cruzamentos em que me encontro - entre o Estado, a garantia de direitos e o mercado -, percebo que se produzem formas de existência que são mais valorizadas que outras: aquelas que já nascem com determinadas características e que precisem de intervenções estatais mínimas. De acordo com Guareschi, Lara, e Adegas (2010), esse é o sujeito ideal que entra para a formulação das minhas ações. Portanto, muitas vidas ficam de fora. Dizem que não há o que fazer por elas, a não ser afastá-los do convívio social, seja em instituições de assistência social, tutelados pelo Estado, seja pelo encarceramento e o extermínio. Os pobres, os negros e os moradores de periferia fazem parte destes indesejáveis sociais (Coimbra, 2006).

No meio acadêmico, sabe-se que minhas ações passaram pela necessidade de institucionalização, na forma de legislação, marcos civis e de direitos para que pudesse efetivar-se para um maior número de pessoas. Mas não estou aqui para falar disso e sim das minhas possibilidades de resistência, dos caminhos que tracei intermezzo, compondo outras relações nos meus encontros. E, por isso, a importância de narrar meu encontro com o Corpo. Esse corpo afirmou a sua vida e sua diferença desde a primeira tentativa de apagamento, e mesmo em situação de prisão, encontrou meios de libertar-se e continuar compondo-se. Me sinto como ele. Por isso, ao contar a sua história, componho-me, como dizia Benjamin (1987).

Não podemos pensar-nos como isolados do que acontece ao nosso redor. Dessa forma, enxergo ao Corpo e a mim mesma como uma dobra possível em relação aos jogos de poder (Pelbart, 1989). Nossa existência se compõe de uma forma para logo em seguida desfazer-se e compor-se novamente, sempre em meio aos acontecimentos das nossas vidas, conectadas a um contexto sócio-histórico. Somos formas provisórias. 
Em muitos momentos, o interior e exterior dessas formas se confundem. No exterior, efervescem os engendramentos macropolíticos, as relações de poder; no interior, a ação cotidiana, micropolítica, que através de diferentes agentes, dobram-se de maneiras diferentes, singulares e descontínuas. Só somos em função desses acontecimentos. E neste momento.

Assim, prefiro enxergar a mim mesma como uma "pensador[a] do Fora" ${ }^{27}$ (Pelbart, 1989) que dialoga com aquilo que me compõe do lado de fora, mas sem se entregar totalmente ao seu poder, resistindo à dissolução no seu turbilhão de forças. Produzo diferença através do meu posicionamento ético. Atuo na macropolítica, mas não estou inteiramente submissa a ela. Não vejo o Corpo apenas como "aquilo que pode e deve ser pensado" (Bernardes, 2012, p. 181), que precisa ser interiorizado e individualizado para melhor ser governado. Mas sim, me experimento em relação a ele, como alteridade. Posso modificar as regras, criar novas configurações e novas práticas ético-estético-políticas. Permito-me pensar na nossa relação com o outro e com o mundo. Abro-me para que potências de diferenciação façam surgir práticas de liberdade.

\section{8 de agosto de 2017}

Hoje eu fiquei pensando em como contar uma história não é apenas ser fidedigno a ela, é também deixar-se transpassar por suas vibrações. Narrar um acontecimento aparentemente simples da vida, sem deixar de dar importância a sua singularidade e não se preocupar em colocá-lo em uma linha do tempo contínua pode ser uma forma de resistir ao silêncio. Benjamin (1987) diz que não contamos mais histórias e que, por isso, nossa capacidade de intercambiar experiências entrou em decadência, fragilizando nossas relações, desvalorizando as pequenas histórias frente à informação - baseada em dados científicos, observáveis e passíveis de verificação. A ciência não dá conta de narrar a vida.

As grandes notícias jornalísticas difundem um discurso pretensamente neutro na busca da verdade sobre as coisas. Nesse processo reduzem "a comunicabilidade da experiência” (Benjamin, 1987, p. 207), alienando o homem do seu próprio percurso histórico, desmerecendo a narrativa de vida frente à produção de verdades universais. As classes economicamente mais vulneráveis parecem ser as mais prejudicadas nesse processo, pois sua palavra é desvalorizada frente ao grande público que privilegia o discurso do Estado e dos especialistas.

Mas há formas de resistir às grandes produções sobre a vida? Para Deleuze e Guattari (2015, p. 36), a literatura menor é um dos caminhos, já que “tudo nela é político”, proliferando conexões, provocando outras intensidades e desterritorializando o desejo que está preso em uma língua maior. A literatura menor nem mesmo precisa ser literatura no sentido estrito da palavra, mas sim se propor a fazer usos estranhos das palavras, "contaminando" o enunciado, fazendo com que algo que seria visto como individual passe a vibrar como história. Percebo essa ligação com a transgressão da língua quando o Corpo se encontra com o hip hop. Ele passa a ver na música uma narrativa política e reconhecer não apenas a sua história, mas de uma coletividade, onde "não há sujeito, há apenas agenciamentos coletivos de enunciação” (Deleuze \& Guattari, 2015, p. 38). 
A cultura hip hop não pode ser analisada apenas por sua dimensão individual. Ela é como uma enunciação coletiva, como um "grito da espécie". Isso nos lembra novamente o que Deleuze e Guattari (2015, p. 43) afirmam sobre Kafka, na sua obra: sabia "liberar uma matéria viva e expressiva que fala por ela mesma”. Ao compor uma narrativa com o Corpo, percebi a importância de valorizar as suas referências culturais, de mapear suas intensidades e como essa matéria viva buscava saídas para as capturas da sua potência. A partir delas, ele continuava a agenciar novas experiências, perseguindo o máximo de desterritorialização possível, produzindo o máximo de diferença, não se deixando reduzir as representações universais sobre a sua vida. Assim também sou eu. Compomos esta história em conjunto, você, eu e o Corpo. Tantos corpos. Tantas intensidades. Transformando a máquina literária na máquina revolucionária onde as potências diabólicas do porvir possam correr soltas.

\section{Notas}

1 "Como o texto ficcional contém elementos do real, sem que se esgote na descrição deste real, então o seu componente fictício não tem o caráter de uma finalidade em si mesma, mas é, enquanto fingida, a preparação de um imaginário” (Mota, 2011, p. 2).

2 Para Foucault (2016), o aparelho penitenciário coloca no lugar do infrator condenado o deliquente. No primeiro está em análise o ato infracional; já na delinquência, está em questão a vida. A operação penitenciária, em sua função de reeducação e ressocialização, se ocupa de totalizar a existência do deliquente de forma a produzir uma afinidade identitária: amarrar o sujeito ao seu delito e fazer coincidir o crime e o criminoso.

3 O autor propõe a escrita de um romance "partido ao meio" como o Visconde de Ítalo Calvino. Utiliza-se de recursos da escrita acadêmica e da literária, inspirado na "literatura menor" de Franz Kafka (Deleuze \& Guattari, 2015). Seu protagonista, o Corpo, é trabalhado através das suas referências pessoais - literatura, música, experiências - e da produção acadêmica, na busca de uma escrita coletiva, onde a própria voz do autor confunde-se com a do personagem.

4. Assim opera como figura identitária, como nome próprio, carregando todas as linhas de segmentaridade que lhe fazem característica individual. Mas também como corpo indiferenciado, como corpo coletivo, de qualquer um e de ninguém, como um possível agenciamento coletivo (Giordani, 2016). 
5 “É preciso entender por acontecimento não uma decisão, um tratado, um reino, uma batalha, mas uma relação de forças que se inverte, um poder confiscado, um vocabulário retomado e voltado contra seus utilizadores, uma dominação que se enfraquece, se distende, se envenena e uma outra que faz sua entrada, mascarada. As forças que se encontram em jogo na história não obedecem nem a uma destinação, nem a uma mecânica, mas ao acaso da luta (Foucault, 2017, p. 28).

6 Aqui nos referimos ao conceito de Instituições Totais, desenvolvido por Goffmann (1961), e seus efeitos perniciosos na produção da mortificação do Eu. Separando os internos da sociedade por um prazo nem sempre claramente determinado; impondo uma vida isolada e trancafiada, sob o comando de uma administração extremamente rígida e rigorosa.

7 De acordo com o conceito de virtualidade de Foucault (2016), é preciso exercer controle sobre os comportamentos das classes perigosas desde o início de suas vidas, para minimizar o efeito de seus desvios. Por isso o corpo mal nasceu e já era por muitos considerado mau.

$8 \quad$ Foucault (2005).

9 Em O Visconde Partido ao Meio de Ítalo Calvino (1996), partes aparentemente opostas - a bondade e a maldade - separadas são caricaturas e juntas compõem a humanidade do protagonista.

10 Para Espinosa o corpo é determinado por afecções que resultam dos encontros. Das afecções derivam movimentos que nos fazem passar de uma maior (alegria) ou menor (tristeza) perfeição, conforme o encontro componha, ou ao contrário, decomponha-nos. $\mathrm{O}$ poder de ser afetado pode apresentar-se como potência de agir, na medida em que permite afecções ativas ou como potência de padecer quando é preenchido por paixões (Deleuze, 2002).

11 A Política se desdobra em Política Pública de Educação. Na diversidade que opera uma política pública é condição de criação e expansão da potência na medida em que linhas maleáveis permitem flexibilizar territórios existenciais - no caso do personagem, encontros para além daqueles impulsionados pela família. Também nessa faceta a Política assume função e, ao encontrar linhas de segmentaridade dura, na medida em que traça diretrizes nacionais de aprendizagem, homogeneíza e corta singularidades (Deleuze \& Parnet, 2004). Nessa dinâmica é preciso inscrever a Política numa leitura extramoral: sem condição prévia de valoração não sabemos que efeitos terão as afecções dela derivadas. Em seu cotidiano há somente embate dos jogos de interesse, do caldo conflitivo em que a realidade materializa-se como obra do acaso (Foucault, 2017).

12 Para Augusto (2011), a escola não atende mais as necessidades dos sujeitos na sociedade contemporânea, mas que ela ainda existe dessa forma pois serve a um propósito: produzir dados para controle das populações. 
13 Atualmente os ditos "alunos-problemas" são mantidos na instituição escolar através de programas de aprovação continuada, já que o local se tornou um importante observatório de suas ações, dando início à construção da biografia criminal (Augusto, 2011).

14. Aqui fazemos alusão ao conceito Lapassadiano de Instituições e sua relação direta com a Burocracia, entendendo essa como uma questão fundamentalmente política e operando como um tipo de relação de poder que atravessa a vida social. Destacamos o conceito de Batismo Burocrático, que se nutre na ideologia do saber e sustenta-se em uma espécie de pedagogia diretiva (Lapassade, 2016). Encontra-se mais sobre o tema no livro Grupos, organizações e instituições de Georges Lapassade.

15 Movimento cultural que surgiu nos EUA, na década de 70, que discutia a crescente violência, o tráfico de drogas, a pobreza, o racismo, a dificuldade de acesso à educação e lazer dos moradores dos subúrbios, buscando "conscientizar, educar, humanizar, promover, instruir e divertir os moradores da periferia, além de reivindicar direitos e o respeito a esse povo" (Fochi, 2007, p. 63)

16 Deleuze \& Guattari (2015).

17 Deleuze (2002).

18 Inspirada na letra da canção "Esquiva da Esgrima" do rapper Criolo (2014): "cada maloqueiro tem um saber empírico".

19 Do inglês americano "thug life", expressão criada pelo rapper 2 Pac (Tupac Sharuk), traduzida pelos Racionais MC'S (2002) como “vida loka”. Refere-se ao estilo de vida do jovem de periferia que se insere no mercado de consumo através da criminalidade.

20 Fazer um favor ou ato ilícito para alguém, como assaltar ou entregar entorpecentes.

21 Quando o crime passa a ser considerado um meio de obter renda para o autossustento, ou seja, um trabalho.

22 Pessoa que gerencia o dinheiro do ponto de venda de drogas (a "boca") reportandose diretamente ao Patrão (chefe do tráfico de drogas de uma região ou bairro).

23 Coimbra (2006).

24 "Fechar" significa envolver-se ou ser parte de uma facção criminosa.

25 Criminalidade. 
26 Inspirado em "Estamos vivos, irmãos! Estamos vivos", frase de luta proferida por KL Jay, importante DJ da cena hip hop brasileira e ex-integrante dos Racionais MC's. Fala sobre a resistência ao extermínio da juventude negra periférica, dizendo aos jovens que continuar vivo é uma vitória que deve ser comemorada em meio a tanta violência.

27 Para Pelbart (1989), a pensadora do fora permite-se um jogo, uma troca, um contato com o caos sem se dissolver na loucura (ausência de obra). Nessa troca com o fora - aquilo sem nome, sem ordem -, a pensadora tenta se afirmar na dobra; como uma invaginação flexível que evita a exposição total ao fora, mas que nela encontra intensidades.

\section{Referências}

Augusto, A. (2011). Escola, Uso de Drogas e Violência. Verve, 19, 117-133. Recuperado de $<$ https://revistas.pucsp.br/index.php/verve/article/view/8671/6444>

Bauman, Z. (1998). O Mal-Estar na Pós Modernidade. Rio de Janeiro: Zahar.

Benjamin, W. (1987). Magia e Técnica, Arte e Politica: ensaios sobre literatura e história da cultura. São Paulo: Brasiliense.

Bernardes, A. G. (2012). Potências no Campo da Saúde: o cuidado como experiência ética, política e estética. Barbarói, 36, 175-190. Recuperado de $<$ https://online.unisc.br/seer/index.php/barbaroi/article/view/2029/2161>

Calvino, I. (1996). Visconde Partido ao Meio. São Paulo: Companhia das Letras.

Coimbra, C. M. B. (2006). Direitos Humanos e Criminalização da Pobreza. In Anais do I Seminário Internacional de Direitos Humanos, Violência e Pobreza. Rio de Janeiro: UERJ. Recuperado de https://app.uff.br/slab/uploads/texto54.pdf

Criolo. (2014). Esquiva da Esgrima. In Convoque seu Buda (CD) São Paulo: Oloko Records. Recuperado de $<$ https://www.youtube.com/watch?v=-1cI4nYIQqs $>$

Deleuze, G. (1988). O Abecedário de Gilles Deleuze. Recuperado de $<$ http://stoa.usp.br/prodsubjeduc/files/262/1015/Abecedario+G.+Deleuze.pdf $>$

Deleuze, G. (2002). Espinosa: filosofia prática. São Paulo: Escuta.

Deleuze, G. \& Guattari, F. (2015). Kafka: por uma literatura menor. Belo Horizonte: Autêntica. Deleuze, G. \& Parnet, C. (2004). Diálogos. Lisboa: Relógio D’Água.

Fochi, M. A. B. (2007). Hip Hop Brasileiro: tribo urbana ou movimento social? FACOM, 17, 61-69. Recuperado de http://www.faap.br/revista faap/revista facom/facom_17/fochi.pdf

Foucault, M. (2005). Em Defesa da Sociedade. São Paulo: Martins Fontes.

Foucault, M. (2016). Vigiar e Punir: nascimento da prisão. Petrópolis, RJ: Vozes.

Foucault, M. (2017). Microfísica do Poder. Rio de Janeiro: Paz e Terra.

Giordani, T. M. A. (2016). Nomadismo e Sociedade de Controle: estudo sobre os "malucos" em uma tese partida ao meio. Tese de Doutorado, Programa de Pós-graduação em Psicologia Social e Institucional, Universidade Federal do Rio Grande do Sul, Porto Alegre, RS.

Goffman, E. (1961). Manicômios, Prisões e Conventos. São Paulo: Perspectiva. 
Guareschi, N. M. F., Lara, L., \& Adegas, M. A. (2010). Políticas Públicas entre o Sujeito de Direitos e o Homo œconomicus. Psico, PUCRS, 41(3), 332-339. Recuperado de $<\underline{\text { http: } / / \text { revistase- }}$ letronicas.pucrs.br/ojs/index.php/revistapsico/article/view/8163/5854>

Kafka, F. (2009). O Processo. São Paulo: Marin Claret.

Lapassade, G. (2016). Grupos, organizações e instituições. Petrópolis, RJ: Vozes.

Mota, R. A. (2011). O Conceito de Ficção: o diálogo de Saer com Iser. ReVeLe, 2, 134-143.

Pelbart, P. P. (1989). Da Clausura do Fora ao Fora da Clausura: loucura e desrazão. São Paulo: Brasiliense.

Racionais MC's. (1997). Diário de um Detento. In Sobrevivendo ao Inferno (CD). São Paulo: Cosa Nostra. Recuperado de $<$ https://www.youtube.com/watch?v=er-bYI9-3hM $>$

Racionais MC's. (2002). Vida Loka: parte II. In Nada como um Dia após o Outro Dia. São Paulo: Zimbabwe Records. Recuperado de $<$ https://www.youtube.com/watch? $\mathrm{v}=$ ahEllnyfHbI $>$ Rauter, C. (2007). Clínica e Estratégias de Resistência: perspectivas para o trabalho do psicólogo em prisões. Psicologia \& Sociedade, 19(2), 42-47. Recuperado de < $\underline{\text { http://www.scielo.br/ }}$ scielo.php?pid $=\mathrm{S} 0102-71822007000200006 \&$ script $=$ sci abstract\&tl ng $=$ pt $>$

Superintendência de Serviços Penitenciários - SUSEPE. (2017). Departamento de Segurança e Execução Penal. Mapa Prisional de 17 de maio. (Intranet).

\section{VANESSA BRANCO CARDOSO \\ https://orcid.org/0000-0003-2210-0515}

Mestranda em Psicologia Social e Institucional pelo Programa de Pósgraduação da Universidade Federal do Rio Grande do Sul (UFRGS). Bolsista CAPES.

Endereço: Instituto de Psicologia UFRGS, Programa de Pós-graduação em Psicologia Social e Institucional, Rua Ramiro Barcelos, 2600 - Térreo Bairro Floresta - Porto Alegre/RS. CEP: 90035-003.

Email: card.vanessa@gmail.com

\section{LUTIANE DE LARA \\ https://orcid.org/0000-0002-9075-9824}

Doutora em Psicologia Social e Institucional pela Universidade Federal do Rio Grande do Sul (UFRGS). Mestre em Psicologia Social e da Personalidade pela Pontifícia Universidade Católica do Rio Grande do Sul (PUCRS). Coordenadora e Docente do Curso de Psicologia do Centro Universitário Metodista (IPA), Porto alegre, RS.

Email: lutianelara@gmail.com 


\section{TIAGO MELGAREJO DO AMARAL GIORDANI}

https://orcid.org/0000-0003-4814-8517

Doutor em Psicologia Social e Institucional pela Universidade Federal do Rio Grande do Sul (UFRGS). Mestre em Educação pela Universidade Federal de Santa Maria (UFSM). Docente do Curso de Psicologia da Pontifícia Universidade Católica do Rio Grande do Sul (PUCRS).

Email: tiagomagiordani@yahoo.com.br

\begin{tabular}{|l|l|}
\hline \multirow{3}{*}{ Histórico } & $\begin{array}{l}\text { Submissão: 17/4/2018 } \\
\text { Revisão: 03/3/2020 } \\
\text { Aceite: 25/5/2020 }\end{array}$ \\
\hline \multirow{3}{*}{ Contribuição dos autores } & $\begin{array}{l}\text { Concepção: VBC, LL } \\
\text { Coleta de dados: VBC } \\
\text { Análise de dados: VBC, LL } \\
\text { Elaboração do manuscrito: VBC, LL, TMAG } \\
\text { Revisões críticas de conteúdo intelectual } \\
\text { importante: LL, TMAG } \\
\text { Aprovação final do manuscrito: VBC, LL }\end{array}$ \\
\hline Consentimento de uso de imagem & Não se aplica. \\
\hline Aprovação, ética e consentimento & Não se aplica. \\
\hline Financiamento & Não se aplica. \\
\hline
\end{tabular}

